\title{
STUDY OF THE INTERFACE AND DURABILITY OF THE ADHESION BETWEEN PHOTOVOLTAIC CELLS AND CONCRETE-BASED FAÇADE PANELS
}

\author{
MATTHIEU HORGNIES, FABIENNE LEGRAND, EMMANUEL BONNET \& \\ ISABELLE DUBOIS-BRUGGER \\ Lafarge Holcim R\&D, France
}

\begin{abstract}
The last generations of solar cells are known to promote the use of renewable energies thanks to their higher efficiency and better aesthetics. However, the recent developments of the Building-Integrated Photovoltaic cells (BIPV) requires the installation of photovoltaic panels on the vertical façade of residential and office buildings (and not only on their roofs) in order to produce more electricity and to reduce the seasonal mismatch between the production and the consumption of electricity. In this case, researches were done to use concrete as a direct support of the solar cells and/or photovoltaic film (in the place of common structures based-on glass or metal). Experiments were performed to establish if the ultra-high-performance fibre-reinforced concrete (UHPFRC) could be a good candidate to manufacture aesthetical façade panels functionalized by photovoltaic cells. A technical process that can be described by pouring the fresh concrete directly on the backside of the photovoltaic cells, previously placed at the bottom of the formwork and coated by specific adhesives, was developed and patented. A broad range of methods and accelerated tests (observations by optical and scanning electron microscopy, adhesion and bending flexural tests, UV aging and water condensation tests, freeze-thaw cycling, etc.) was used to study the interface between photovoltaic components and concrete, and to establish if the adhesion could be durable. The results highlighted that the multi-layer technique, composed of flexible photovoltaic cells, structural adhesive and UHPFRC is a durable composite after hardening, which can resist to a broad range of environmental aggressions.
\end{abstract}

Keywords: adhesion, mechanical tests, durability, photovoltaic, concrete, interface.

\section{INTRODUCTION}

The decisions of the European Commission done during the last decade have set targets in terms of $\mathrm{CO}_{2}$ emissions reduction and promotion of the use of renewable energies [1], [2]. The last generations of solar cells tend to answer these issues thanks to their higher efficiency. However, their use in the field of Building-Integrated Photovoltaic (BIPV) [3]-[5] requires the installation of photovoltaic panels not only on the roof, but also on the vertical façades of the residential and office buildings [6], [7]. Indeed, the integration of photovoltaic panels on the building envelope appears to be a relevant solution to produce more electricity, but also to reduce the seasonal mismatch (between the production and the consumption of electricity) [8].

Based-on previous results showing that the surface of concrete can be designed in terms of smoothness and flatness (by choosing the right mix-designs and moulding conditions [9]-[11]), some experiments were conducted to establish if this kind of concrete-based solution could be an alternative to glass-based and metallic-based structures to manufacture aesthetical façade panels with photovoltaic function. Indeed, a technical process that can be described by the direct pouring of fresh concrete on the backside of the photovoltaic cells, previously placed at the bottom of the formwork and coated by specific adhesives, was developed and patented in 2015. 
After a description of the manufacturing process of the photovoltaic concrete-based façade panels, this paper will focus on the data resulting from different analyses and accelerated aging tests (characterisation of the interface, adhesion and bending flexural tests, freeze-thaw cycling, water condensation tests, UV aging tests) that were undertaken to study the robustness of the adhesion.

\section{MATERIALS AND METHODS}

\subsection{Concrete mix-design, photovoltaic cells and adhesives}

The results shown in this paper were obtained using an ultra-high-performance concrete (UHPFRC) mix-design. It was prepared by mixing Portland cement (CEM I 52.5), limestone filler, silica fumes, sand $(0-1 \mathrm{~mm}, \mathrm{D} 50$ at $307 \mu \mathrm{m})$, polyvinyl alcohol-based fibres and super-plasticizer (polyoxyalkylene polycarboxylate-based). A water to cement ratio (W/C) of 0.26 was used. Two types of flexible photovoltaic (PV) cells were used: one using a polycrystalline silicon technology and another one using the amorphous silicon technology. Three types of adhesives were tested: an epoxy-based (Resipoly chrysor C6123), another one made of styrene-acrylic copolymers (Acronal), and an adhesive tape made of polyisoprene-polyisobutylene. Table 1 describes the composition of the glues, the conditions of application and the different PV cells used. In some cases, the backside of the PV cells was sandblasted (during 30s using sand $(0-1 \mathrm{~mm})$ ) prior to apply the epoxybased glue in order to increase the roughness (and to try to promote the adhesion).

\subsection{Method to integrate the PV cell with concrete}

The process of integration of the PV cells on concrete can be detailed in four steps (Figs. $1-3)$ :

1. The backside of the PV cells is coated by a layer of glue or by an adhesive tape,

2. The PV cells are deposited at the bottom of the mould (the frontside of the PV cell face to the mould surface),

3. The fresh concrete mix-design is poured into the mould,

4. The hardened sample is removed from the mould after 18 hours, before being stored under ambient conditions $\left(25^{\circ} \mathrm{C} / 50 \%\right.$ of relative humidity $\left.(\mathrm{RH})\right)$ or before performing accelerated aging tests.

Table 1: Description of the different PV cells and adhesives.

\begin{tabular}{|c|c|c|c|}
\hline PV cells & Adhesives & $\begin{array}{l}\text { Method to apply the glue on } \\
\text { the backside of the PV cells }\end{array}$ & $\begin{array}{c}\text { Drying step/ } \\
\text { other }\end{array}$ \\
\hline \multirow{2}{*}{$\begin{array}{l}\text { Flexible PV cell from } \\
\text { SolarModul } \\
\text { (polycrystalline silicon) }\end{array}$} & $\begin{array}{l}\text { Epoxy-based } \\
\text { glue }\end{array}$ & \multirow{2}{*}{$\begin{array}{l}\text { Using a comb to deposit } \\
\text { more than } 400 \mathrm{~g} \text { of glue } \\
\text { per } \mathrm{m}^{2} \text { of PV cell }\end{array}$} & $\begin{array}{l}\text { No drying } \\
\text { step* }\end{array}$ \\
\hline & $\begin{array}{l}\text { Styrene-acrylic } \\
\text { copolymers }\end{array}$ & & $\begin{array}{l}\text { Drying step } \\
(>15 \mathrm{~min})\end{array}$ \\
\hline $\begin{array}{l}\text { Flexible PV cell from } \\
\text { Solariflex } \\
\text { (amorphous silicon) }\end{array}$ & $\begin{array}{l}\text { Polyisoprene- } \\
\text { polyisobutylene }\end{array}$ & Adhesive tape & $\begin{array}{l}\text { No drying } \\
\text { step }\end{array}$ \\
\hline
\end{tabular}

* In some cases, the backside of PV cells was sandblasted prior to apply the epoxy-based glue. 


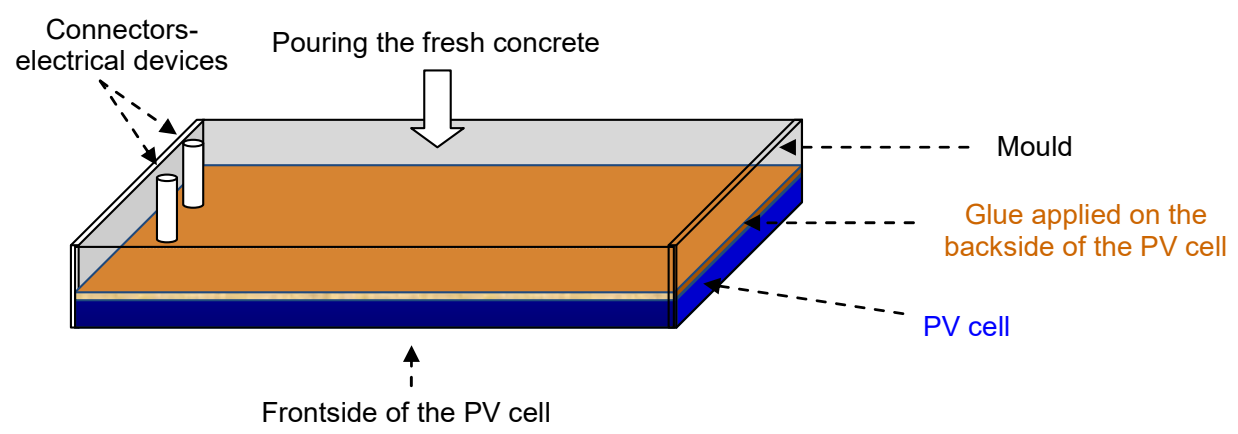

Figure 1: Drawing of the process of integration of the PV cell with concrete.

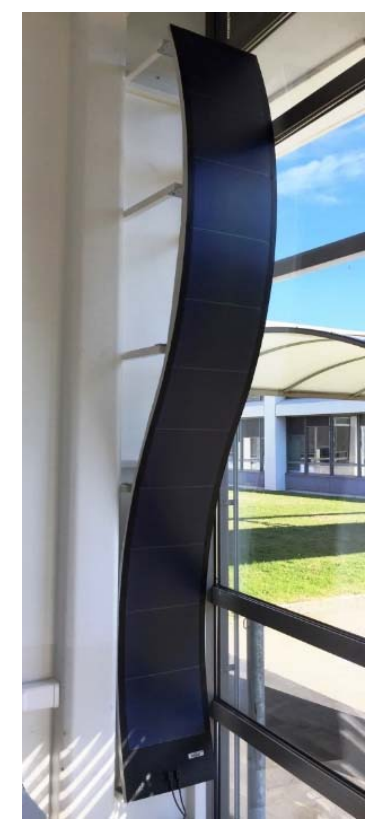

Figure 2: Concrete-based curved panel integrating a flexible 3m-long PV cell.
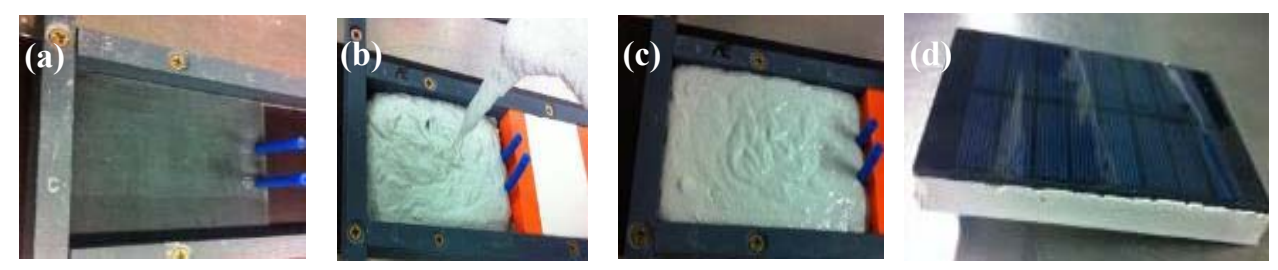

Figure 3: Pictures showing the integration process: (a) PV cells coated by glue and placed at the bottom of the mould; (b) Fresh concrete poured into the mould; (c) Sample during hardening; (d) Hardened concrete integrating the PV cell after demoulding. 


\subsection{Methods of characterisation}

A confocal profilometer (STIL Micro measure full-field 3D with a $350 \mu \mathrm{m}$ light pen, a spot of $1.8 \mu \mathrm{m}$ and a working distance of $12.9 \mathrm{~mm}$ ) was used to measure the topographic profiles of the backside of PV cells and calculate the arithmetic mean of the surface deviations from the mean line $(\mathrm{Sa})$ and the core roughness depth (Sk). Some samples were cut, impregnated in resin and then polished before being characterised in Back Scattering Electron mode (BSE) using a high-resolution field effect gun scanning electron microscope (SEM FEG Quanta 400 from FEI Company, accelerating voltage of $15 \mathrm{keV}$ and current intensity of 1nA). The composition of the sections was also analysed by EDS (XFlash ${ }^{\circledR}-100$ SDD detector from Bruker).

The adhesion and the mechanical properties were studied by using the pulling out method and the four points bending flexural test (see details in $\S 3.3$ and 3.4). Moreover, the samples were subjected to several accelerated aging methods during several months in order to study the durability of the adhesion between concrete, glue and PV cell:

- Storage at $60^{\circ} \mathrm{C} / 100 \% \mathrm{RH}$ using a condensation chamber,

- Storage in a to a UV-rays chamber to perform a 2-steps cycling: (i) $60^{\circ} \mathrm{C}$ with UV during $4 \mathrm{~h}$, and (ii) $50^{\circ} \mathrm{C}$ without $\mathrm{UV}$ during $4 \mathrm{~h}$,

- Storage in a freeze-thaw chamber to perform a 4-steps cycling: (i) $45 \mathrm{~min}$ at $+9^{\circ} \mathrm{C}$ under water, (ii) decrease of temperature during $3 \mathrm{~h}$ until $-18^{\circ} \mathrm{C}$, (iii) $35 \mathrm{~min}$ at $-18^{\circ} \mathrm{C}$ under air, (iv) increase of temperature during $40 \mathrm{~min}$ until $+9^{\circ} \mathrm{C}$.

\section{RESULTS}

\subsection{Characterisation of the interface by SEM and profilometry}

As shown by Fig. 4, the SEM observations of polished sections confirmed that no air void was detected at the interface between concrete, epoxy-based glue and the backside of the PV cell. The UHPFRC was characterised by the presence of sand mixed into the hydrated cement paste containing the limestone-based filler. Moreover, the analyses by EDS established that the epoxy glue was composed of fine aggregates (charges) made of magnesium sulphate (talc) and barium sulphate. The thickness of the layer made of epoxy glue was estimated to $300-900 \mu \mathrm{m}$ by comparing several SEM pictures.

As shown in Table 2, the measurements done by profilometry established that the sandblasting of the backside of the PV cells was efficient to increase the roughness of the surface. An average roughness of $1 \mu \mathrm{m}$ was then measured after $30 \mathrm{~s}$ of sandblasting.

\subsection{Durability of the samples after aging tests}

Table 3 summarizes all the results obtained after subjecting the samples to different aging tests (condensation, UV aging and freeze-thaw cycling). These tests were discriminating because the de-bonding at the interface between the adhesive layer and the PV cells was sometimes rapidly detected after the start of the test. Indeed, the results highlighted that the sandblasting of the backside of the PV cells was necessary to avoid any rapid de-bonding at the interface between the epoxy-based glue and the PV cells. Moreover, the tests established that the glue made of styrene-acrylic copolymers was less efficient that the one made of epoxy or the tape made of polyisoprene-polyisobutylene.

As a main conclusion of these aging tests, the application of epoxy-based glue on the sandblasted backside of the PV cell seems to be the more robust process of integration. The use of an adhesive tape can also be used as a second solution, especially because its use does not require any sandblasting of the backside of the PV cells. 


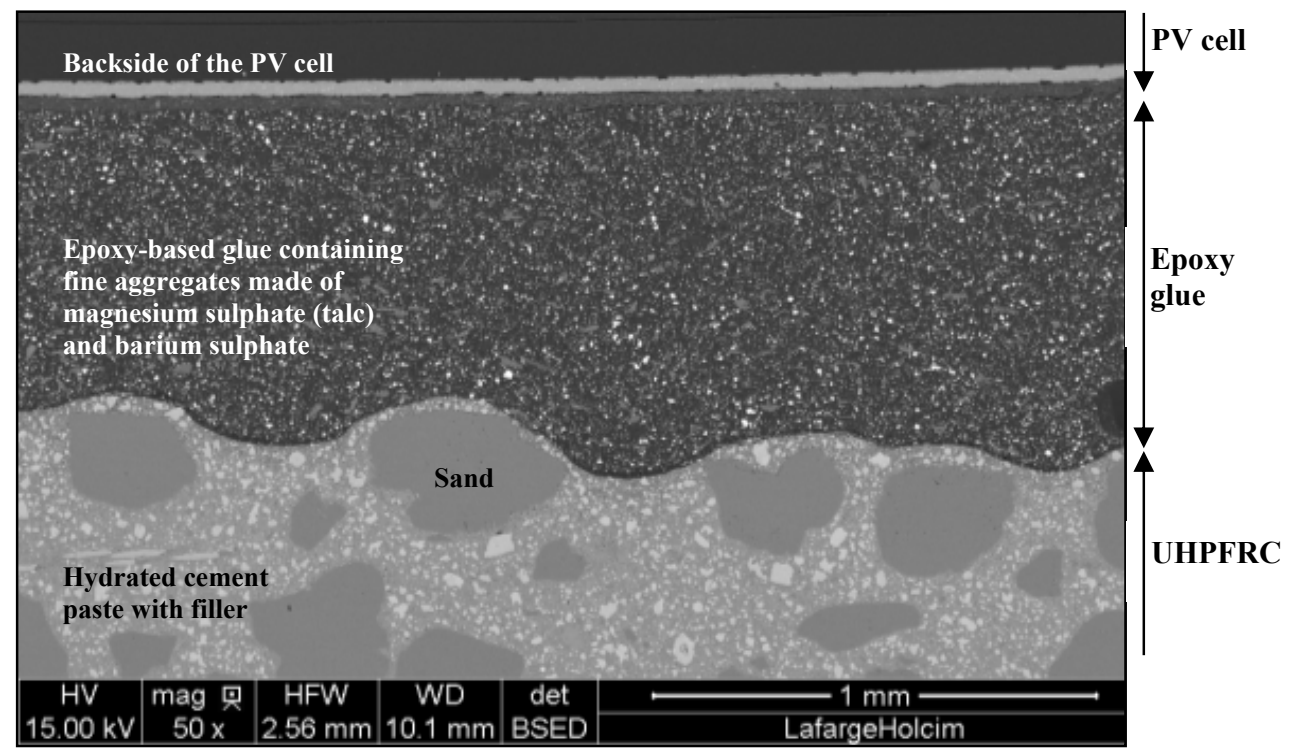

Figure 4: SEM picture of a polished section of the interface between concrete, epoxybased glue and the backside of a PV cell.

Table 2: Roughness of the backside of the PV cells, before and after the sandblasting.

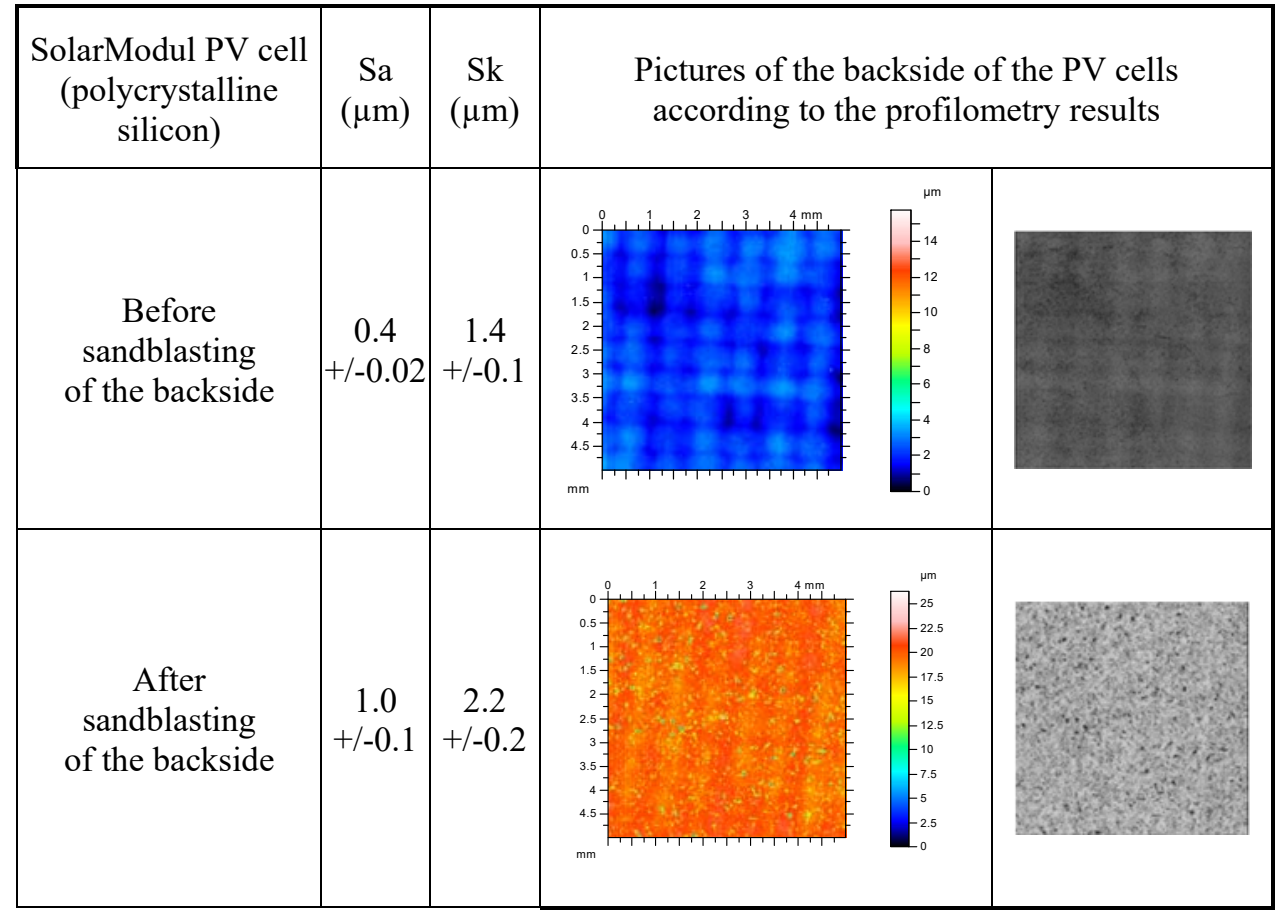


Table 3: Summary of the results obtained during the accelerated aging tests.

\begin{tabular}{|c|c|c|c|c|c|}
\hline PV cells & Adhesives & $\begin{array}{l}\text { Drying } \\
\text { step }\end{array}$ & $\begin{array}{c}\text { Condensation } \\
\text { test }\end{array}$ & $\begin{array}{l}\text { UV-aging } \\
\text { test }\end{array}$ & $\begin{array}{l}\text { Freeze-thaw } \\
\text { cycling }\end{array}$ \\
\hline $\begin{array}{c}\text { SolarModul } \\
\text { without } \\
\text { sandblasting }\end{array}$ & $\begin{array}{l}\text { Epoxy-based } \\
\text { glue }\end{array}$ & / & $\begin{array}{l}\text { De-bonding } \\
\text { after } 1 \text { week }\end{array}$ & $\begin{array}{l}\text { De-bonding } \\
\text { after } 1 \text { week }\end{array}$ & $\begin{array}{l}\text { De-bonding } \\
\text { after } 3 \text { cycles }\end{array}$ \\
\hline \multirow{4}{*}{$\begin{array}{l}\text { SolarModul } \\
\text { with } \\
\text { sandblasted } \\
\text { backside }\end{array}$} & $\begin{array}{l}\text { Epoxy-based } \\
\text { glue }\end{array}$ & I & $\begin{array}{l}\text { No de-bonding } \\
\text { after } 9 \text { months }\end{array}$ & $\begin{array}{l}\text { No de-bonding } \\
\text { after } 9 \text { months }\end{array}$ & $\begin{array}{c}\text { No de-bonding } \\
\text { after } \\
800 \text { cycles }\end{array}$ \\
\hline & \multirow{3}{*}{$\begin{array}{l}\text { Styrene-acrylic } \\
\text { copolymers }\end{array}$} & $30 \mathrm{~min}$ & $\begin{array}{l}\text { De-bonding } \\
\text { after } 3 \text { months }\end{array}$ & $\begin{array}{l}\text { No de-bonding } \\
\text { after } 7 \text { months }\end{array}$ & $\begin{array}{l}\text { De-bonding } \\
\text { after } \\
105 \text { cycles }\end{array}$ \\
\hline & & $24 \mathrm{~h}$ & \multirow{2}{*}{$\begin{array}{l}\text { De-bonding } \\
\text { after } 1 \text { week }\end{array}$} & 1 & 1 \\
\hline & & $48 \mathrm{~h}$ & & 1 & I \\
\hline Solariflex & $\begin{array}{c}\text { Adhesive tape } \\
\text { (polyisoprene- } \\
\text { polyisobutylene) }\end{array}$ & / & $\begin{array}{l}\text { No de-bonding } \\
\text { after } 6 \text { months }\end{array}$ & $\begin{array}{l}\text { No de-bonding } \\
\text { after } 6 \text { months }\end{array}$ & $\begin{array}{c}\text { No de-bonding } \\
\text { after } \\
600 \text { cycles }\end{array}$ \\
\hline
\end{tabular}

\subsection{Adhesion tests}

The adhesion between concrete, adhesive and PV cell was quantified by doing pulling out tests using a dynamometer. Intending to define accurately the measurement surface, a circular part was first cut up to the basic concrete. Then, a metallic disc of the corresponding size (50 mm-diameter), and related to a dynamometer, was stuck on the testing surface using epoxy-based glue. Table 4 summarize the average results deduced from the 4 to 6 adhesion tests performed on each type of sample.

The tests done on the sample manufactured without any sandblasting of the backside of the PV cell showed very low values of adhesion, which can explain why a rapid de-bonding occurred at the interface between the glue and the non-sandblasted PV cells during the aging tests. On the other side, the adhesion tests done on the samples manufactured by applying the epoxy-based glue on a sandblasted backside of the PV cells highlighted a very good adhesion $(>1 \mathrm{MPa}$ ) with a de-bonding zone always located into the layer of epoxy. These specific results were confirmed by the adhesion tests done after 800 cycles of freezethaw. Finally, the pulling out tests done with samples manufactured using an adhesive tape showed a lower, but enough significant, level of adhesion $(0.2 \mathrm{MPa})$, with a de-bonding zone located into the layer of adhesive.

\subsection{Four point bending flexural test}

The mechanical properties of the samples $(320 \mathrm{~mm}$ length, $50 \mathrm{~mm}$ width, $15 \mathrm{~mm}$ thickness) composed of PV cell, glue and concrete was studied using four point bending flexural tests [12] and a speed of $0.03 \mathrm{~mm} / \mathrm{s}$. They were compared to the ones of a reference UHPFRC 
sample (without neither glue nor PV cell). All the results detailed in Fig. 5 and Table 5 were acquired after storing the samples at $20^{\circ} \mathrm{C} / 98 \% \mathrm{RH}$ for 14 and 28 days, respectively.

The results acquired after 14 days of cure showed no negative effect on the bending properties due to the presence of both the PV cell (with sandblasted backside) and the layer of epoxy-based glue. The significant cohesion of this type of sample (as previously established by the adhesion tests) was confirmed after 28 days of cure: $\sigma \mathrm{LOP}$ and $\sigma \mathrm{MOR}$ values were equal or better than the ones for the UHPFRC reference (by taking into account the total thickness of the sample). This kind of results seems to highlight a better ductility for the samples constituted of a sandblasted PV cell, epoxy-based glue and concrete (as shown by the high value of $\varepsilon$ MOR compared to reference).

On the other hand, the adhesion of the PV cell using an adhesive tape did not show any significant influence on the mechanical properties, which are close to the ones of the reference UHPFRC after 14 and 28 days of cure at $20^{\circ} \mathrm{C} / 98 \% \mathrm{RH}$.

\section{CONCLUSIONS}

The process allowing the direct integration of photovoltaic cells with fresh concrete during the moulding time was described. The application of a layer of glue on the backside of the PV cells, or the use of an adhesive tape, is then required before pouring the fresh concrete to make possible the photovoltaic functionalization of the façade panel made of concrete. However, the different pulling out tests and aging tests (water condensation, UV aging, freeze thaw) done after hardening of concrete established that the maximum adhesion was obtained if the epoxy-based glue is applied on the backside of PV cell previously sandblasted (in order to increase its roughness).

Table 4: Summary of the results of the adhesion tests.

\begin{tabular}{|c|c|c|c|c|c|}
\hline PV cells & Adhesives & $\begin{array}{c}\text { Storage/ } \\
\text { aging step }\end{array}$ & $\begin{array}{l}\text { Adhesion } \\
(\mathrm{MPa})\end{array}$ & $\begin{array}{c}\text { De-bonding } \\
\text { zone }\end{array}$ & $\begin{array}{c}\text { Images of de-bonding } \\
\text { zone after the } \\
\text { pulling out test }\end{array}$ \\
\hline $\begin{array}{l}\text { SolarModul } \\
\text { without } \\
\text { sandblasting }\end{array}$ & $\begin{array}{c}\text { Epoxy-based } \\
\text { glue }\end{array}$ & $\begin{array}{l}28 \text { days at } \\
20^{\circ} \mathrm{C} / \\
50 \% \mathrm{RH}\end{array}$ & $<0.1$ & $\begin{array}{l}\text { Between } \\
\text { epoxy and } \\
\text { backside of } \\
\text { PV cell }\end{array}$ & \\
\hline $\begin{array}{l}\text { SolarModul } \\
\text { with } \\
\text { sandblasted } \\
\text { backside }\end{array}$ & $\begin{array}{c}\text { Epoxy-based } \\
\text { glue }\end{array}$ & $\begin{array}{l}28 \text { days at } \\
20^{\circ} \mathrm{C} / \\
50 \% \mathrm{RH}\end{array}$ & $\begin{array}{c}1.18 \\
+/-0.20\end{array}$ & $\begin{array}{l}\text { Between } \\
\text { epoxy and } \\
\text { concrete }\end{array}$ & 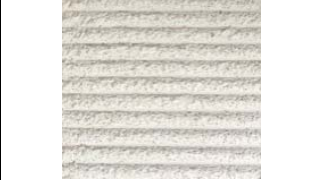 \\
\hline $\begin{array}{l}\text { SolarModul } \\
\text { with } \\
\text { sandblasted } \\
\text { backside }\end{array}$ & $\begin{array}{c}\text { Epoxy-based } \\
\text { glue }\end{array}$ & $\begin{array}{l}800 \text { cycles } \\
\text { of freeze } \\
\text { thaw }\end{array}$ & $\begin{array}{c}0.34 \\
+/-0.12\end{array}$ & $\begin{array}{l}\text { Between } \\
\text { epoxy and } \\
\text { concrete }\end{array}$ & 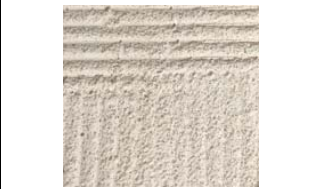 \\
\hline Solariflex & \begin{tabular}{|c|} 
Adhesive tape \\
(polyisoprene- \\
polyisobutylene)
\end{tabular} & $\begin{array}{c}28 \text { days at } \\
20^{\circ} \mathrm{C} / \\
50 \% \mathrm{RH}\end{array}$ & $\begin{array}{c}0.19 \\
+/-0.02\end{array}$ & $\begin{array}{c}\text { Into the } \\
\text { adhesive tape }\end{array}$ & \\
\hline
\end{tabular}




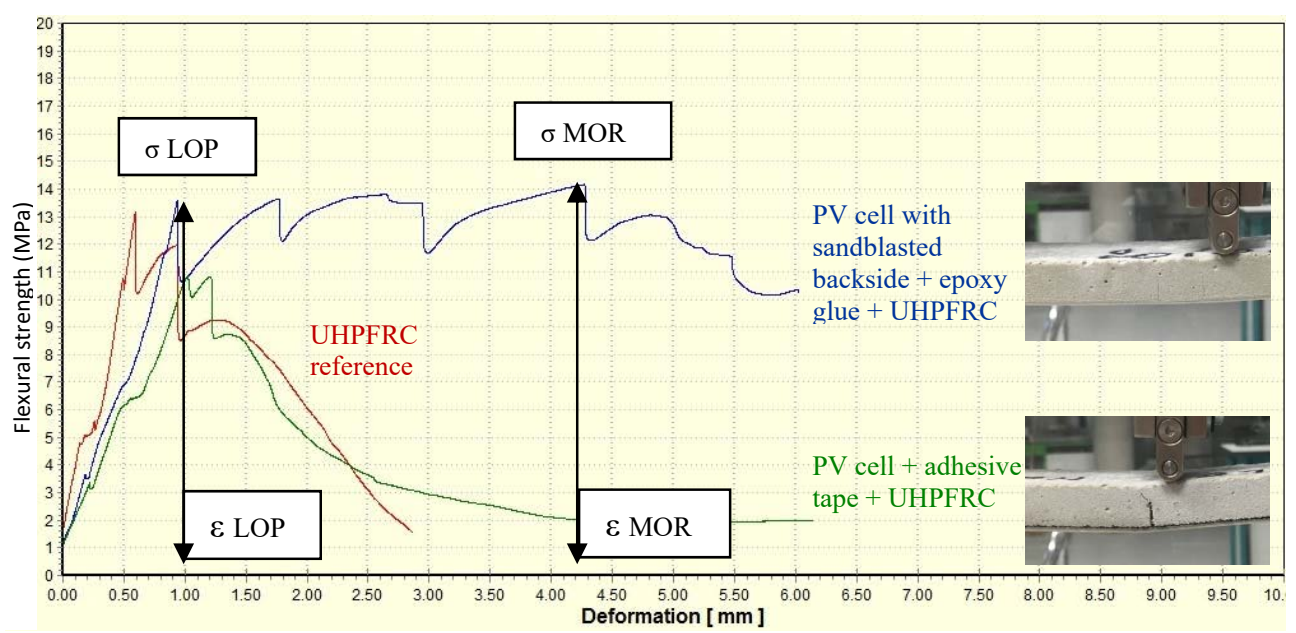

Figure 5: Data from four point bending flexural tests (after 14 days of cure, $20^{\circ} \mathrm{C} / 98 \%$ $\mathrm{RH})$. (LOP=Limit of Proportionality; MOR=Maximum of Rupture).

Table 5: Results of four point bending flexural tests (after 28 days of cure, $20^{\circ} \mathrm{C} / 98 \%$ $\mathrm{RH})$. (LOP=Limit of Proportionality; MOR=Maximum of Rupture).

\begin{tabular}{|c|c|c|c|c|}
\hline $\begin{array}{c}\text { After } 28 \text { days of cure } \\
\left(98 \% \mathrm{RH} / 20^{\circ} \mathrm{C}\right)\end{array}$ & $\begin{array}{c}\sigma \mathrm{LOP} \\
(\mathrm{MPa})\end{array}$ & $\begin{array}{c}\varepsilon \mathrm{LOP} \\
(\mathrm{mm})\end{array}$ & $\begin{array}{c}\sigma \mathrm{MOR} \\
(\mathrm{MPa})\end{array}$ & $\begin{array}{c}\varepsilon \mathrm{MOR} \\
(\mathrm{mm})\end{array}$ \\
\hline Reference UHPFRC & $\begin{array}{c}17.2 \\
+/-1.6\end{array}$ & $\begin{array}{c}0.8 \\
+/-0.1\end{array}$ & $\begin{array}{c}17.8 \\
+/-1.0\end{array}$ & $\begin{array}{c}0.8 \\
+/-0.1\end{array}$ \\
\hline $\begin{array}{c}\text { SolarModul PV cell with } \\
\text { sandblasted backside } \\
\text { epoxy glue + UHPFRC }\end{array}$ & $\begin{array}{c}17.7 \\
+/-0.8\end{array}$ & $\begin{array}{c}0.8 \\
+/-0.1\end{array}$ & $\begin{array}{c}23.3 \\
+/-3.3\end{array}$ & $\begin{array}{c}4.9 \\
+/-2.0\end{array}$ \\
\hline $\begin{array}{c}\text { Solariflex PV cell } \\
+ \text { adhesive tape } \\
+ \text { UHPFRC }\end{array}$ & $\begin{array}{c}14.9 \\
+/-0.5\end{array}$ & $\begin{array}{c}1.0 \\
+/-0.1\end{array}$ & $\begin{array}{c}16.6 \\
+/-1.0\end{array}$ & $\begin{array}{c}1.1 \\
+/-0.1\end{array}$ \\
\hline
\end{tabular}

This efficient adhesion between all the layers (PV cell, glue and concrete) was confirmed even after 800 cycles of freeze-thaw cycles. Moreover, the bending flexural tests done on this composite material highlighted better performance in terms of ductility compared to the reference samples made of UHPFRC. As a second option, the use of an adhesive tape to stick the PV cell with fresh concrete is also possible. However, this method of integration showed lower adhesion levels than in case of applying the epoxybased glue on the sandblasted backside of PV cell and did not improve the bending flexural performances.

As a conclusion, the integration of flexible PV cells on a substrate based on ultra-high performances concrete allows manufacturing architectural and aesthetical façade panels, with possibilities to design flat, but also curved shapes. More investigations are now 
scheduled to study the performances and the durability of the system in outdoor exposure conditions.

\section{ACKNOWLEDGEMENTS}

The authors would like to thank Alain Chonier, Sylvain Duchand, Pascal Jay, Sébastien Lombard, Gérard Molinès and Xavier Salvador for their help during this study.

\section{REFERENCES}

[1] European Commission, 2020 by 2020: Europe's climate change opportunity. Communication from the commission to the European parliament, the Council, the European Economic and social committee and the committee of the regions. COM 30 final: Brussels, 2008.

[2] European Commission, A roadmap for moving to a competitive low carbon economy in 2050. Communication from the commission to the European parliament, the Council, the European Economic and social committee and the committee of the regions. COM 112 final, Brussels, 2011.

[3] Ceron, I., Caamaño-Martin, E. \& Neila, F.J., State of art of building integrated photovoltaic products. Renewable Energy, 58, pp. 127-133, 2013.

[4] Cronemberger, J., Almagro Corpas, M., Ceron, I., Caamaño-Martin, E. \& Vega Sanchez, S., BIPV technology application: highlighting advances, tendencies and solutions through solar Decathlon Europe houses. Energy and Buildings, 83, pp. 4456, 2014.

[5] Shukla, A.K., Sudhakar, K. \& Baredar, P., A comprehensive review on design of building integrated photovoltaic system. Energy and Buildings, 128, pp. 99-110, 2016.

[6] Polo Lopez, C., Frontini, F., Bonomo, P. \& Scognamiglio, A., PV and façade systems for the building skin. Analysis of design effectiveness and technological features. Proceedings of the $29^{\text {th }}$ European Photovoltaic Solar Energy Conference and Exhibition, Amsterdam, 2014.

[7] Verberne, G. et al., BIPV products for façades and roofs: a market analysis, Proceedings of the 29 ${ }^{\text {th }}$ European Photovoltaic Solar Energy Conference and Exhibition, Amsterdam, 2014.

[8] Evola, G. \& Margani, G., Renovation of apartment blocks with BIPV: energy and economic evaluation in temperate climate. Energy and Buildings, 130, pp. 794-810, 2016.

[9] Gueit, E., Darque-Ceretti, E., Tintillier, P. \& Horgnies, M., Surfactant-induced growth of calcium hydroxide coating at the mortar surface. Journal of Coating Technologies Research, 9, pp. 337-346, 2012.

[10] Horgnies, M., Chen, J.J. \& Darque-Ceretti, E., XPS investigation of the composition of the external surface of concrete after demoulding, cleaning and carbonation. Surface and Interface Analysis, 45, pp. 830-836, 2013.

[11] Horgnies, M. \& Chen, J.J., Superhydrophobic concrete surfaces with integrated microtexture. Cement and Concrete Composites, 52, pp. 81-90, 2014.

[12] European Standard EN 1170-5. Precast concrete products - Test method for glassfibre reinforced cement - Part 5: Measuring bending strength, Complete bending test method, 1997. 